\title{
Returns to Investment in University Education - Economics Career at Continental University
}

\author{
Gustavo Ilich Loayza Acosta ${ }^{1}$, Naisha Alyssa Bernardo Reyes ${ }^{1} \&$ Margarita Elluz Calle Arancibia ${ }^{1}$ \\ ${ }^{1}$ Universidad Continental, Peru \\ Correspondence: Gustavo Ilich Loayza Acosta, Universidad Continental, Peru.
}

Received: February 13, 2020

Accepted: March 8, 2020

Online Published: January 6, 2021

doi:10.5430/rwe.v12n1p166

URL: https://doi.org/10.5430/rwe.v12n1p166

\begin{abstract}
The present work analyzes the returns to the years of superior schooling of graduates of Economics Career at Continental University within the labor market of the region Junín of the period 2019. For this purpose, the returns to education are investigated under the normal assumptions of Mincer's equation, and later the incorporation of the instrumental variable: school of origin is proposed, in order to correct the problem of endogeneity. Finally, to correct the problem of selection bias, Heckman's technique is used: two-stage regression. This consists of first analyzing the probability of accessing the labor market in the Junín region in terms of variables such as: geographic location, school of origin, age, direct costs. Subsequently, analyzing the return to years of schooling. Likewise, it is important to specify that in the modeling of the probability a second regression is estimated incorporating the variable Academic Grade in order to be able to study the Sheepskin Effect. The results obtained showed that the return to years of schooling is $0.8 \%$, which is not significant and is not corrected for Heckman's selection bias. We also have that the R2 is $10.11 \%$ which is very low for this type of cross-sectional data. This result is explained by the degree of rootedness of the graduates in staying in the Huancayo province and the low migration to other labor markets. In addition, this means that they do not have better working conditions that can be transformed into higher income.
\end{abstract}

Keywords: rate of return to education, endogeneity, selection bias, instrumental variables, sheepskin effect

\section{Introduction}

As many authors rightly argue, the health of an economy is reflected in its labor market; therefore, it is crucial to foster the development of this market through the different sectors of the economy. Consequently, given that the return to higher education for graduates of Economics Career at Continental University is dependent on the labor market, it is important to analyze the characteristics of the professionals who make up the labor supply, as well as their counterparts, that is, the demand for professionals by companies and the different sectors to which these companies belong. Since both would end up determining the salary income of the professionals and, consequently, the rate of return to the years of schooling.

The main motivation for the elaboration of the research is to determine the rate of return to the years of schooling of the graduates of Economics Career at Continental University for the period 2019; for this, the Mincer equation is used and the gaps in the remunerations of the graduates are analyzed. On the other hand, it also seeks to identify which are the determinants that affect the probability of graduates to access the labor market, and also analyze the effect that the academic degree variable has on graduates to access it. To do this, we will use information from graduates Economics Career. It is also important to mention that the Economics Career is a relatively young career and we have graduates from 6 years of age or less; the econometric software used will be Stata 15.

The development of the research is presented in different sections: in section 1, we will present the theoretical framework; in section 2, the objectives; in section 3, the context; in section 4, the modeling, challenge of the alternative, experimental development, methods and design; in subsection 4.1 we have the sample; in section 4.2, the estimation; in section 5, the results and finally in section 6 , we present the conclusions.

\section{Literature Review}

There are extensive studies regarding the analysis of returns to education, both for the methodological aspect of the estimation, and for the formulation of the model and the theoretical framework that supports it. But there are two studies that are primarily pioneers in the study of education and its contribution to the formation of human capital, 
among them we have Becker (Becker, 1975) with Human Capital: A Theorical and Empirical analysis with special reference to education, and Mincer (Mincer, 1974) with his work Schooling, experience and earnings.

Among the studies of the methodological aspect we have (Espinoza \& Quiroz, 2009), which make an analysis of the different assumptions behind the formulation of the Mincer equation, as well as the ways to make the estimates. Within the main assumptions it observes, there is the fact that the Mincer equation does not distinguish between initial and mature work experience, as well as the assumption that while studying one does not work, that schooling always ends up preceding work and finally, the contribution that education can have on experience is not appreciated in income.

With respect to returns to education, it is important to note that there is a problem of endogeneity; since education affects income and, on the other hand, people with higher incomes can acquire more education. In general, all of this is corrected with the instrumental variables' technique; then, when using this technique, there is a detail: it may be showing only the performance of a certain group that is being treated, as it points out (Paredes, Alonso, Bara, \& Sabate, 2000).

Within the analysis of returns to education in Peru, we have the work of (Yamada, 2006), where he exposes the reality of higher education in the country and the returns that these generate through the Peruvian labor market.

In the historical 12-year study they conducted to see the returns to education and experience in Peru for the 1985-1997 period, they found that after the drop in employment and income in the early 1990s, there was an improvement, but that it was not homogeneous, but rather concentrated in certain particular groups (youth and women); likewise, income growth was slightly higher in the early 1990s and slowed from the 1995 (Saavedra \& Maruyama, 1999).

Studies for Dominican Republic show a return to years of schooling of $6.9 \%$ in 2015, which has a downward trend; at the same time, these returns have a certain degree of convexity, so that there are up to eight times greater returns at the university level compared to the primary level. Therefore, if the estimates of the Mincer equation are disaggregated by educational level, we have to invest in one more year of education, be it primary, secondary or university, since it would be associated with a return of $2.3 \%, 4.3 \%, 18.6 \%$ respectively (Parodi, Ramirez, \& Thompson, 2017).

There is an important study carried out in Galicia in which the analysis of the education variable is mentioned in an endogenous and not exogenous way, as most of the models propose; likewise, the sample used is of young workers between 19-34 years old, so the study raises strong implications. Among them is the fact that having little experience, the experience squared is not very significant. In this sense, studies conducted in Galicia on the Mincer equation show a return to investment in education of $5.6 \%$ (Freire \& Teijeiro, 2010).

There are also studies of the Mincer equation for Chile, where it also focuses on returns to education in a disaggregated manner, so that different returns can be obtained for different educational levels; likewise, it extends the study with the Sheeepskin effect, which is associated with the value of obtaining a certificate or a degree of satisfactory completion of the study period, which is interpreted in the labor market as a sign of the level reached. (Sapelli, 2003)

Other studies focus on analyzing wage differences, such as the exploratory analysis carried out at the national and regional level in Chile (Fuentes \& Herrera, 2015), and find that, of the 15 regions analyzed, the most important determinant of future income is gender. In this sense, this indicates that this difference is becoming more accentuated, generating gender inequality, which is subsequently influenced by the years of schooling that represent an average return of $10 \%$.

Other studies focus more properly on the estimation form of the Mincer equation. So much so that the study by (Blundell, Dearden, \& Sianesi, 2001) shows a way to estimate the relationship between income and education through simple regression, such as more sophisticated regressions with heterogeneous returns, with instrumental variables and impact assessment techniques, in order to distinguish between groups that received treatment (higher education) and those that did not.

In the same line, we also have the study by (Butler, 2004). This study analyzes the selection bias, which comes from studying a subgroup that is in the labor market and receives income.

We can also find the study: La adquisición de capital humano: un modelo teórico y su contrastación (Rodríguez, 1992). This study analyzes the individual's family and how it influences the acquisition of human capital, as well as 
the social class, the parents' work status and the size of the municipality of residence; given that they also influence or are determinants of income.

With a five-year study of the returns to education for heads of households in the Puno region (Paz, Mamani, \& Quilla, 2016), they found returns of $12.36 \%$ in salary, which makes education in that region very profitable.

On the other hand, Cesar Gutierrez's study discusses the consideration of human capital within the theoretical framework as physical capital, giving it the same treatment within the modeling of current versus future consumption decisions or also the studies that consider it as a simple cost-benefit analysis. However, the author notes that this form of modeling does not take into account the fact that it depends not only on applicable funds, but more importantly on the capacity and effort of the individual. Furthermore, it is also assumed that it is the individuals themselves who make the decision to invest in human capital, when in reality it is the parents who make this decision for the benefit of their children. For this reason, a model that incorporates the capacity of the individual is proposed.

\section{Methods}

The data used in this study corresponds to a survey carried out on the graduates of Economics Career at Continental University. From this sample, we intend to study the behavior of the income only of those who are classified as employed according to their labor situation as of 2019. In addition, it is important to point out that Economics Career is a career that was created in 2008, so the first graduating class was in March 2013.

With respect to the estimation of the model, a simple regression of the Mincer equation is proposed at the beginning, to later correct the problem of endogeneity incorporating an instrumental variable that would be the school of origin. Finally, a two-stage regression is performed to correct for selection bias with academic performance as measured by the score variable.

The model to be estimated has the following representation:

$$
\ln Y=\beta \_0+\beta \_1 \text { AosEdu }+\beta \_2 \operatorname{Exp}+\beta \_3[\operatorname{Exp}]^{\wedge} 2+\varepsilon \_t
$$

Where:

$\ln Y$ : Natural logarithm of income

AosEdu: Years of Education

Exp: Years of experience

Exp: Years of experience squared

$\varepsilon_{-} \mathrm{t}$ : Term of disturbance

\subsection{Instrumental Variables}

Given that the modeling of the returns to education presents the problem of endogeneity, the school of origin variable will be incorporated as an instrumental variable within the model in order to be able to correct the double causality.

$$
\ln Y=\beta \_0+\beta \_1 \text { AosEdu }+\beta \_2 \operatorname{Exp}+\beta \_3[\operatorname{Exp}]^{\wedge} 2+\text { cole_pro }+\varepsilon \_t
$$

Where:

$\operatorname{lnY}$ : Natural logarithm of income

AosEdu: Years of Education

Exp: Years of experience

Exp: Years of experience squared

$\varepsilon_{-} \mathrm{t}$ : Term of disturbance

cole_pro: School of origin

\subsection{Selection Bias}

The model also needs to correct for selection bias, since, according to Heckman, only the income sample is being worked with. Therefore, a function of probability of accessing the labor market must be specified, which in this paper has the following modeling:

$$
\mathrm{LFP}=\mathrm{P}\left(\mathrm{Z} \_\mathrm{i}=1\right)=\lambda \_0+\lambda \_1 \text { Sexo }+\lambda \_2 \text { Edad }+\lambda \_3 \operatorname{Costos}+\lambda \_4 \text { Nota }+\varepsilon \_\mathrm{t}
$$

Where:

Sexo: The gender of the graduates 
Costos: Costs associated with university education

Nota: The note of the graduates of the Universidad Continental

LFP: The probability of accessing the labor market.

$\varepsilon_{-} \mathrm{t}$ : Term of disturbance

\subsection{Sheepskin Effect}

Next, the academic grade variable of the modeling will also be incorporated, in order to be able to estimate the Sheepskin Effect. Therefore, we proceed to specify the academic grade as an explanatory variable within the function of probability of accessing the labor market, which will have the following modeling:

$$
\mathrm{LFP}=\mathrm{P}\left(\mathrm{Z} \_\mathrm{i}=1\right)=\lambda \_0+\lambda \_1 \mathrm{Sexo}+\lambda \_2 \mathrm{Edad}+\lambda \_3 \operatorname{Costos}+\lambda \_4 \text { Nota }+\lambda \_5 \mathrm{Grado}+\varepsilon \_\mathrm{t}
$$

Where:

Sexo: The gender of the graduates

Costos: Costs associated with university education

Nota: The note of the graduates of the Universidad Continental

LFP: The probability of accessing the labor market.

Grado: Diploma achieved by the graduate (academic degree).

$\varepsilon_{-}$t: Term of disturbance

\section{Results}

The results call much attention, because they do not go according to what is expected; but, at the same time, they allow to draw very interesting conclusions which will be detailed next.

First, with respect to the descriptive analysis of the study variables, we have that, on average, the income of graduates from the School of Economics amounts to S/. 1,599,034 with a strong standard deviation of S/1,000.00 approximately, which would be showing a strong heterogeneity of wage income.

Second, $82 \%$ of the graduates manage to enter the labor market, which demonstrates the good job opportunities that Continental University's economics program has been generating. Likewise, the average number of years of education until graduating from university is 16 years with a standard deviation of +-1 year.

Thirdly, the average number of years of experience is 2.92 , which would indicate a certain lack of experience on the part of the graduates, for which the short time that the economics course at the Continental University has trained professionals in this field must be taken into account.

Thus, the average grade of the graduates is 13.6 , which would be showing an inadequate performance compared to other universities in the region. On the other hand, $41 \%$ of the graduates come from state schools, and the average cost of university education is about S/. 25 861.64, having an average age of 26 years, which represents a relatively young population of graduates, of which $61 \%$ work in the public sector.

Finally, we also have that $46 \%$ of the graduates are women. (See Table 1)

Table 1. Descriptive analysis of the study variables

\begin{tabular}{|c|c|c|c|c|c|c|c|c|c|c|c|c|c|}
\hline \multirow[t]{6}{*}{ Sample } & & \multicolumn{12}{|c|}{ Variables } \\
\hline & \multirow{5}{*}{$\begin{array}{l}\text { INGRESOS } \\
\text { (Income) }\end{array}$} & \multirow{4}{*}{$\begin{array}{l}\text { ACCE } \\
\text { TRAB } \\
\text { (Acces to }\end{array}$} & \multirow{2}{*}{$\begin{array}{l}\text { AOS } \\
\text { EDU }\end{array}$} & \multirow{2}{*}{$\begin{array}{l}\text { AOS } \\
\text { EXP }\end{array}$} & AOS & \multirow[b]{2}{*}{ NOTA } & \multirow{2}{*}{$\begin{array}{c}\text { LUGAR } \\
\text { PRO }\end{array}$} & COLE & \multirow[b]{2}{*}{ costos } & \multirow{4}{*}{$\begin{array}{l}\text { EDAD } \\
\text { (Age) }\end{array}$} & \multirow{3}{*}{$\begin{array}{c}\text { LUGAR } \\
\text { TRAB } \\
\text { (Work }\end{array}$} & \multirow{5}{*}{$\begin{array}{c}\text { INSTU TR } \\
\text { (Work } \\
\text { Institution) }\end{array}$} & \multirow{5}{*}{$\begin{array}{r}\text { SEXo } \\
\text { (Sex) }\end{array}$} \\
\hline & & & & & EXP2 & & & PRO & & & & & \\
\hline & & & (Years & (Years & (Years & (Note) & (Place of & (School of & (Costs) & & & & \\
\hline & & & & & & & & & & & & & \\
\hline & & work) & Edu) & Exp) & Exp2) & & origin) & origin) & & & place) & & \\
\hline & 1599.034 & 0.828 & 16.39 & 2.921 & 11.857 & 13.606 & 1.214 & 0.414 & 25861.64 & 26.434 & 1.055 & 0.614 & 0.462 \\
\hline Median & 1500.000 & 1.000 & 16.00 & 3.000 & 9.000 & 13.530 & 1.000 & 0.000 & 25575.00 & 26.000 & 1.000 & 1.000 & 0.000 \\
\hline Maximum & 6000.000 & 1.000 & 20.50 & 7.500 & 52.250 & 17.320 & 4.000 & 1.000 & 46500.00 & 39.000 & 3.000 & 1.000 & 1.000 \\
\hline Minimum & 0.000 & 0.000 & 15.00 & 0.500 & 0.250 & 10.560 & 1.000 & 0.000 & 9300.00 & 21.000 & 0.000 & 0.000 & 0.000 \\
\hline
\end{tabular}




\begin{tabular}{|c|c|c|c|c|c|c|c|c|c|c|c|c|c|}
\hline Std. Dev & 1091.309 & 0.379 & 1.094 & 1.830 & 12.635 & 1.013 & 0.637 & 0.494 & 6246.33 & 3.295 & 0.789 & 0.489 & 0.500 \\
\hline Skewness & 0.601 & -1.734 & 1.526 & 0.456 & 1.219 & 0.531 & 3.350 & 0.350 & 0.51 & 0.896 & 1.011 & -0.467 & 0.152 \\
\hline Kurtosis & 3.883 & 4.008 & 6.120 & 2.148 & 3.603 & 4.589 & 13.895 & 1.123 & 4.96 & 3.923 & 4.134 & 1.218 & 1.023 \\
\hline Jarque-Bera & 13.431 & 78.844 & 115.0 & 9.422 & 38.107 & 22.077 & 988.71 & 24.257 & 29.65 & 24.550 & 32.463 & 24.45 & 24.17 \\
\hline Probability & 0.001 & 0.000 & 0.000 & 0.009 & 0.000 & 0.000 & 0.000 & 0.000 & 0.00 & 0.000 & 0.000 & 0.000 & 0.000 \\
\hline Sum & 231860.0 & 120.000 & 2377 . & 423.5 & 1719.2 & 1972.9 & 176.00 & 60.000 & 3749938. & 3833.0 & 153.000 & 89.000 & 67.000 \\
\hline Sum Sq. Dev. & 17200000 & 20.690 & 172.4 & 482.3 & 22989 & 147.86 & 58.372 & 35.172 & 56200000 & 1563.6 & 89.559 & 34.37 & 36.04 \\
\hline Observaciones & 145.000 & 145.000 & 145.0 & 145.0 & 145.00 & 145.00 & 145.00 & 145.00 & 145.00 & 145.00 & 145.000 & 145.0 & 145.0 \\
\hline
\end{tabular}

With respect to the histogram, only the note (Nota) and cost (Costos) variables tend to a normal distribution. (See Figure 1)
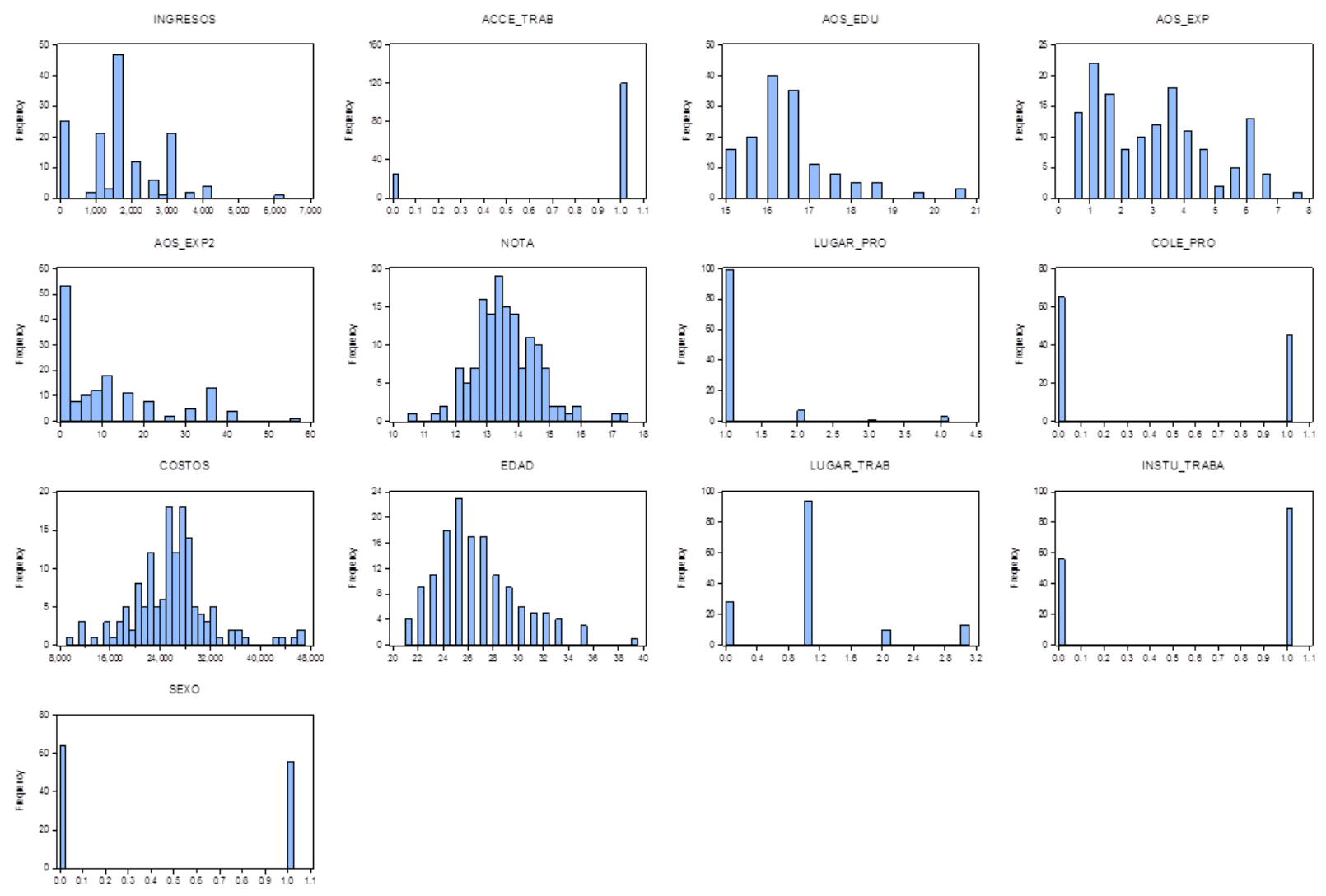

Figure 1. Histogram of the study variables

According to the scatter diagram, between the variables years of education (AOS_EDU) and the logarithm of income (LN_ING) a weak negative correlation is observed, which is contrasted with the covariance analysis between both variables, which will be detailed later (See Table 2). 

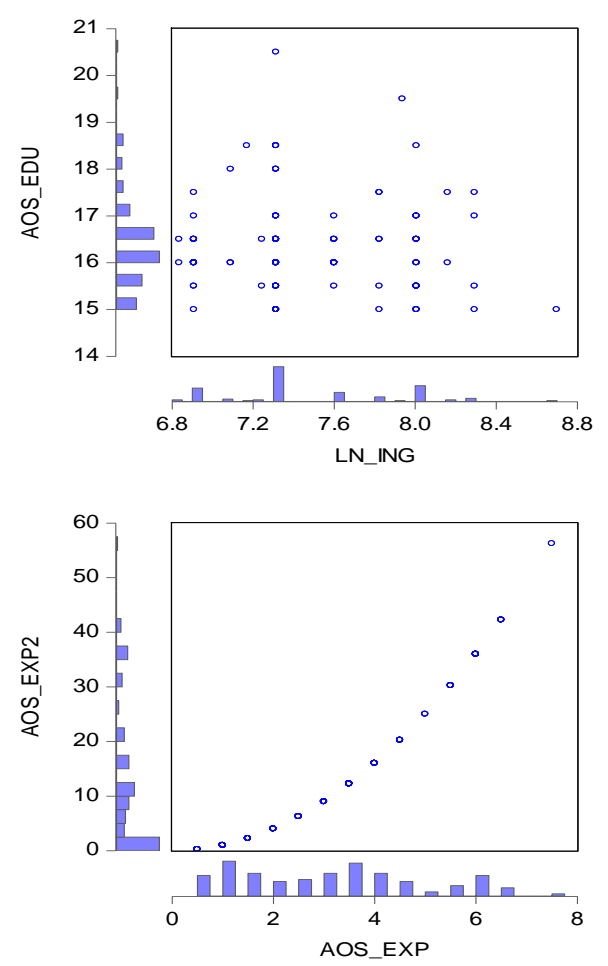

Figure 2. Scatter plot of the logarithmic variables of income, years of study, years of experience

Table 2. Covariance analysis of the study variables

\begin{tabular}{llllll}
\hline \multicolumn{1}{l}{ Covariance Analysis: Ordinary } & 1120 & & & \\
\hline Sample & & & & & \\
\hline Included observations:120 & & & & \\
\hline Covariance Correlation & LN ING & AOS EDU & AOS EXP & AOS EXP2 & COLE PRO \\
\hline LN ING & 0.1722630 & & & & \\
\cline { 2 - 6 } (Ln Income) & 1.0000000 & & & & \\
\hline AOS EDU & -0.0132890 & 0.9770660 & & & \\
(Years Edu) & -.0323900 & 1.0000000 & & & \\
\hline AOS EXP & 0.2225120 & -0.3218060 & 3.2747220 & & \\
\cline { 2 - 6 } (Years Exp) & 0.2962580 & -0.1799050 & 1.00000000 & & \\
\hline AOS EXP2 & 1.3657140 & -2.3894620 & 22.1463900 & 160.6210000 & \\
\cline { 2 - 6 } (Years Exp2) & 0.2596340 & -0.1907380 & 0.9656380 & 1.0000000 & \\
\hline COLE PRO & 0.0035570 & 0.0333680 & 0.1561110 & 0.8101740 & 0.2415970 \\
\cline { 2 - 6 } (School of origin) & 0.0174370 & 0.0686790 & 0.1755090 & 0.1300560 & 1.0000000 \\
\hline
\end{tabular}

With respect to the analysis of covariance of the dependent variable logarithm of the income (LN_ING), with the independent variables of the study it has that, with respect to the years of education it is $-3.2 \%$, with the years of experience $29.62 \%$ and the experience squared of $25.96 \%$. 
Table 3. Estimates of the mincer equation

\begin{tabular}{|c|c|c|c|c|}
\hline \multicolumn{5}{|l|}{ Depend Variable: LN ING } \\
\hline \multicolumn{5}{|l|}{ Method: Least Squares } \\
\hline \multicolumn{5}{|l|}{ Sample: 1120} \\
\hline \multicolumn{5}{|l|}{ Included Observations: 120} \\
\hline Variable & Coefficient & Std. Error & t-Statistic & Prob \\
\hline AOS EDU (Years Edu) & 0.008365 & 0.037992 & 0.220167 & 0.8261 \\
\hline AOS EXP (Years Exp) & 0.163649 & 0.079529 & 2.057731 & 0.0419 \\
\hline AOS EXP2 (Years Exp2) & -0.013704 & 0.01129 & -1.213774 & 0.2273 \\
\hline COLE PRO (School of origin) & -0.046221 & 0.077092 & -0.599558 & 0.55 \\
\hline $\mathbf{C}$ & 7.030152 & 0.634541 & 11.07911 & 0 \\
\hline R-squared & 0.101142 & & Mean dependent var & 7.475692 \\
\hline Adjusted R-squared & 0.069878 & & S.D. dependent var & 0.416787 \\
\hline S.E. of regression & 0.401861 & & Akaike info criterion & 1.055849 \\
\hline Sum squared resid & 18.58083 & & Schwarz criterion & 1.171995 \\
\hline Log likelihood & -58.35095 & & Hannan-Quinn Criter & 1.103016 \\
\hline$\overline{\text { F-statistic }}$ & 3.235046 & & Durbin-Watson stat & 1.88137 \\
\hline Prob(F-statistic) & 0.014816 & & & \\
\hline
\end{tabular}

As can be seen in the following regression, the return to years of education is $0.8 \%$ so it is not significant and is not corrected for Heckman's selection bias. We also have that the R2 is $10.11 \%$ which is very low for this type of cross-sectional data (See Table No. 03).

Table 4. Estimates of the mincer equation with selection bias correction

\begin{tabular}{|c|c|c|c|c|}
\hline \multicolumn{5}{|c|}{ Dependent Variable: LN INGRE } \\
\hline \multicolumn{5}{|c|}{ Method: Two-Step Heckman Selection } \\
\hline \multicolumn{5}{|l|}{ Sample: 1145} \\
\hline \multicolumn{5}{|l|}{ Included observations: 145} \\
\hline \multicolumn{5}{|c|}{ Selection Variable: ACCE TRAB } \\
\hline \multicolumn{5}{|c|}{ Coefficient covariance computed usig two-step Heckman method } \\
\hline \multirow[t]{2}{*}{ Variable } & Coefficient & Std. Error & t-Statistic & Prob \\
\hline & \multicolumn{4}{|c|}{ Response Equation - LN_INGRE } \\
\hline AOS EDU (Years Edu) & 0.069954 & 0.045726 & 1.529874 & 0.1283 \\
\hline AOS EXP (Years Exp) & 0.053201 & 0.022008 & 2.417338 & 0.0169 \\
\hline COLE PRO (School of origin) & -0.015597 & 0.074199 & -0.210201 & 0.8338 \\
\hline \multirow[t]{2}{*}{$\mathbf{C}$} & 6.417817 & 0.818293 & 7.842928 & 0 \\
\hline & \multicolumn{4}{|c|}{ Selection Equation - ACCE_TRAB } \\
\hline SEXO (Sex) & 0.01658 & 0.254775 & 0.065078 & 0.9482 \\
\hline EDAD (Age) & 0.081634 & 0.020192 & 4.042908 & 0.0001 \\
\hline COSTOS (Costs) & $-4.54 \mathrm{E}-05$ & $1.81 \mathrm{E}-05$ & -2.503381 & 0.0135 \\
\hline
\end{tabular}




\begin{tabular}{llll}
\hline Mean dependent var & 7.475692 & S.D. dependent var & 0.416787 \\
\hline S.E. of regression & 0.439487 & Akaike info criterion & 3.441358 \\
\hline Sum squared resid & 26.26829 & Schwarz criterion & 3.585062 \\
\hline Log likehood & -242.4985 & Hannan-Quinn criter & 3.49975 \\
\hline
\end{tabular}

According to estimates corrected for selection bias, the return to higher education of graduates is $6.9 \%$; however, this variable is not significant at 5\%. On the other hand, in relation to years of experience we have a return of 5.3\%, which is significant.

With regard to the second regression, which measures access to the labor market, we have that both age and the costs associated with investment in education are significant. While the sex variable is not a determining factor in labor market insertion, which could lead to the conclusion that there is no gender discrimination.

Table 5. Estimation of the mincer equation with selection bias correction and the incorporation of the note variable

\section{Dependent Variable: LN INGRE}

Method: Two-Step Heckman Selection

Sample: 1145

Included observations: 145

\section{Selection Variable: ACCE TRAB}

Coefficient covariance computed using two-step Heckman method

\begin{tabular}{lllll}
\hline Variable & Coefficient & \multicolumn{1}{l}{ Std. Error } & t-Statistic & Prob \\
\hline & \multicolumn{1}{l}{ Response Equation - LN_INGRE } & & \\
\hline AOS_EDU (Years Edu) & 0.057894 & 0.073956 & 0.782808 & 0.4351 \\
\hline AOS_EXP (Years Exp) & 0.063159 & 0.021677 & 2.913674 & 0.0042 \\
\hline C & 6.44775 & 1.096792 & 5.878735 & 0 \\
\hline & Selection Equation & ACCE_TRAB & & \\
\hline SEXO (Sex) & -0.037094 & 0.259942 & -0.142701 & 0.8867 \\
\hline EDAD (Age) & 0.037532 & 0.030194 & 1.243035 & 0.2167 \\
\hline COSTOS (Costs) & $-6.21 E-05$ & $2.04 E-05$ & -3.04227 & 0.0028 \\
\hline NOTA (Note) & 0.121913 & 0.063534 & 1.918853 & 0.0571 \\
\hline Mean dependent var & 7.475692 & S.D. dependent var & 0.416787 & \\
\hline S.E. of regression & 0.389114 & Akaike info criterion & 3.214338 & \\
\hline Sum squared resid & 20.59173 & Schwarz criterion & 3.358042 & \\
\hline Log likehood & -226.0395 & Hannan-Quinn criter & 3.27273 & \\
\hline
\end{tabular}

As observed in the second regression considering the note variable within the modeling, the rate of return to education is reduced to 5.7\%; likewise, the experience variable (AOS_EXP) increases to 6.3\%. Therefore, the indicator of academic performance (Note) needs to be improved, since they represent signals within the labor market. 
Table 6. Estimation of the Mincer Equation with Sheepskin Effect

\begin{tabular}{|c|c|c|c|c|}
\hline \multicolumn{5}{|c|}{ Dependent Variable: LN INGRE } \\
\hline \multicolumn{5}{|c|}{ Method: Two-Step Heckman Selection } \\
\hline \multicolumn{5}{|l|}{ Sample: 1145} \\
\hline \multicolumn{5}{|l|}{ Included observations: 145} \\
\hline \multicolumn{5}{|c|}{ Selection Variable: ACCE TRAB } \\
\hline \multicolumn{5}{|c|}{ Coefficient covariance computed usig two-step Heckman method } \\
\hline Variable & Coefficient & Std. Error & t-Statistic & Prob \\
\hline \multicolumn{5}{|c|}{ Response Equation - LN_INGRE (Ln income) } \\
\hline AOS_EDU (Years Edu) & 0.091513 & 0.091956 & 0.995186 & 0.3214 \\
\hline AOS EXP (Years Exp) & $5.56 \mathrm{E}-02$ & $2.29 \mathrm{E}-02$ & $2.43 \mathrm{E}+00$ & $1.64 \mathrm{E}-02$ \\
\hline $\mathbf{C}$ & 6.002872 & 1.391917 & 4.312666 & 0 \\
\hline \multicolumn{5}{|c|}{ Selection Equation - ACCE_TRAB(Acces to work) } \\
\hline SEXO (Sex) & 0.000661 & 0.26442 & 0.002501 & 0.998 \\
\hline EDAD (Age) & $3.35 \mathrm{E}-02$ & $3.04 \mathrm{E}-02$ & $1.10 \mathrm{E}+00$ & $2.73 \mathrm{E}-01$ \\
\hline COSTOS (Costs) & -.0000588 & 0.0000208 & -2.83051 & 0.0053 \\
\hline NOTA (Note) & 0.108957 & 0.064488 & 1.689587 & 0.0934 \\
\hline GRADO (Academic Degree) & $1.66 \mathrm{E}-01$ & $1.88 \mathrm{E}-01$ & $8.83 \mathrm{E}-01$ & $3.79 \mathrm{E}-01$ \\
\hline Root MSE & 0.407519 & Mean dependent var & 7.475692 & \\
\hline S.D. dependent var & 0.416787 & S.E. of regression & 0.422342 & \\
\hline Akaike info criterion & 3.342374 & Sum squared resid & 24.08034 & \\
\hline Schwarz criterion & 3.506607 & Log likelihood & -234.3221 & \\
\hline Hannan-Quinn criter. & 3.409108 & & & \\
\hline
\end{tabular}

Finally, to see the Sheepskin Effect, the probability of accessing the labor market was estimated with the incorporation of the academic grade variable, which shows interesting results, since the performance of the years of education increases by $16.58 \%$ if the academic grade and degree are completed. However, this result is not significant for the moment.

The labor market faced by the graduates of the professional school of Economics of the Continental University, privileges the work experience, the academic degree and the university degree.On the other hand, the non significant or influential variables at the time of looking for a job are the age of the graduate, the qualification obtained (grade) and the sex. The results of this research, compared with other studies, show that there are similarities and differences in the labor markets. According to Andrade \& Parra (2020) and Ortega (2019) in Colombia, the relevant variables to find are experience and university degree; in contrast, women receive a lower income compared to men. On the other hand, the increase in returns to education according to the level of studies attained is consistent with studies in the Dominican Republic (Castellanos, 2019).

With respect to the $6.6 \%$ rate of return found, it coincides with what Ortega (2019) found in the sense that the rates of return are lower in those universities that are more expensive, "the more expensive IES present lower indicators of return, since the higher income of their graduates does not compensate for the negative effect of higher investment costs in the education acquired at the IES" (p.39). This agrees with the results of this study, in which the unit of analysis is students from the Continental University, which is a private university. 


\section{Conclusion}

- Although more than $80 \%$ of the graduates of the Continental University manage to enter the labor market, the lack of work experience and the tight performance of the Huancayo labor market, leads to inefficient salaries, which would be generating a certain social loss.

- Most of the graduates of the Universidad Continental are young, with an average age of 26, which offers a poor labor situation for them and generates a return of $6.6 \%$ for the years of education; which is, according to estimates, not significant.

- Likewise, there is an internal policy at the level of Peruvian institutions that due to the lack of experience of new entrants, they have to pay what is colloquially known as "derecho de piso", thus generating salaries that are far below what the labor market offers. In addition, the process of entering the labor market begins with professional practices, which represents a very low salary at the beginning.

- The titling process is key, as it generates signaling within the labor market through the Sheepskin Effect. However, since the academic degree variable is not significant at $5 \%$, it cannot be concluded that such an effect exists; nevertheless, it raises the returns to education and increases the probability of accessing the labor market.

- The great differences in salary income that exist among the graduates of the Continental University would be a latent concern for the future, since they generate problems of inequality.

- The degree of rootedness of the graduates in staying in the Huancayo province and the low level of migration to other labor markets means that they do not have better working conditions that could be transformed into higher income.

\section{Acknowledgement}

This research work was financed by the Continental University, since one of its pillars is to create positive impact through research. In this way, it seeks to improve the employability of young talent who are doing their university studies in this house of studies. Likewise, we would like to thank the committee of the Congreso Internacional en Empleabilidad y Mercado Laboral de la Alianza del Pacífico, who gave us the opportunity to present the development of this research in order to transmit information that can be applied and improved in other centers of university studies.

\section{References}

Andrade Lavao, K., \& Parra Aramburo, C. A. (2020). Tasa de retorno de la educación en la ciudad de Cali año 2016.

Becker, G. (1975). Human Capital: A Theorical and Empirical analysis with special reference to education. New York: Nber.

Blundell, R., Dearden, L., \& Sianesi, B. (2001). Estimating the returns to education: models, methods and results. London: University College London and Institute for Fiscal Studies.

Castellanos, G. D. (2019). Disminución de los retornos de la educación en Guatemala. Atlantic Review of Economics: Revista Atlántica de Economía, 2(1), 1.

Espinoza, J., \& Quiroz, E. (2009). Educación e ingresos: aspectos metodológicos y estudios en el Perú. Lima.

Freire, J., \& Teijeiro, M. (2010). Las ecuaciones de Mincer y las tasas de rendimiento de la educación en Galicia. La Coruña: Universidad.

Fuentes, G., \& Herrera, R. (2015). Análisis exploratorio de los determinantes del ingreso de la ocupación principal a nivel nacional y regional en Chile. Concepcion: Universidad de Concepcion.

Mincer. (1974). Shooling, experience and earnings. New York: Nber.

Ortega Martínez, J. C. (2019). Análisis de los retornos de la educación superior en Colombia: una aproximación desde un modelo riesgo-rentabilidad.

Paredes, F. B., Alonso, J. O., Bara, J. R., \& Sabate, J. R. (2000). Rendimientos de la educación y efecto tratamiento. El caso de España. Barcelona: Universitat Autonoma de Barcelona.

Parodi, S., Ramírez, I., \& Thompson, J. (2017). Tasas de retorno de la inversión en educación en República Dominicana (2000-2015). República Dominicana: BID. https://doi.org/10.18235/0000830 
Paz, R., Mamani, P., \& Quilla, J. (2016). Retornos a la educación de los Jefes de Hogar en la Región Puno, 2011 2015. Puno: Revista de investigación Alto Andina.

Saavedra, J., \& Maruyama, E. (1999). Los retornos a la educación y a la experiencia en el Perú: 1985-1997. Lima: Grupo de Análisis para el Desarrollo.

Sapelli, C. (2003). Ecuaciones de mincer y las tasas de retorno a la educación en chile: 1990-1998. Santiago: Pontificia Universidad Católica de Chile.

Yamada, G. (2006). Retornos a la educación superior en el mercado laboral: vale la pena el esfuerzo?. Lima: Pacifico.

\section{Copyrights}

Copyright for this article is retained by the author(s), with first publication rights granted to the journal.

This is an open-access article distributed under the terms and conditions of the Creative Commons Attribution license (http://creativecommons.org/licenses/by/4.0/). 